\title{
COVID-19 compliant and cost effective teaching model for King Abdulaziz University
}

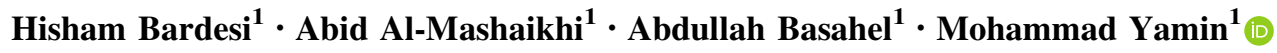

Received: 6 April 2021/Accepted: 17 April 2021/Published online: 10 May 2021

(C) Bharati Vidyapeeth's Institute of Computer Applications and Management 2021

\begin{abstract}
The global pandemic of COVID-19 has been going on for over sixteen months. During this period, we have witnessed a colossal loss of life, property, business, and a degradation of social life. Several different variants or strains of SARS-CoV-2, which causes COVID-19, have been found in different parts of the world. This pandemic has so far infected more than one hundred and thirty five million people, which has caused significant damage to the education sector. The majority of students around the world have lost access to face-to-face classes. While dealing with the crisis, some higher education institutions are still finding it difficult to adapt to alternative ways of imparting education. Many of them are using learning management systems and other online technologies and tools to facilitate online learning. The aim of this manuscript is to propose a cost-effective hybrid teaching model (CeHTM) for the King Abdulaziz University. The proposed model is designed after analyzing two anonymous online feedback surveys in which nearly four thousand students and more than four hundred instructors have participated. The CeHTM is novel as it is the first framework of its kind for imparting education during pandemic. Given the uniformity of educational system in Saudi Arabian universities,
\end{abstract}

Mohammad Yamin

myamin@kau.edu.sa

Hisham Bardesi

hbardesi@kau.edu.sa

Abid Al-Mashaikhi

aalmashaikhi@kau.edu.sa

Abdullah Basahel

abasahel@kau.edu.sa

1 Faculty of Economics and Administration, King Abdulaziz University, Jeddah, Saudi Arabia the proposed model can be used by other Saudi Arabian institutions, and adapted elsewhere, especially in the Middle East and North Africa.

Keywords COVID-19 · Higher education · Online teaching · Virtual classes - Learning management system · Cost effective and hybrid education system

\section{Introduction}

The world is now passing through the third wave of COVID-19, the disease caused by severe acute respiratory syndrome corona-virus 2 (SARS-CoV-2), also known as novel coronavirus. Several new strains of coronavirus have recently emerged in different parts of the world, which are known to be even more aggressive. The virus was first detected in the Wuhan province of China on 31st December 2019, and subsequently declared a global pandemic by the World Health Organisation (WHO) [1] on 12th March 2020. It has since killed about three million people. Unfortunately, there is no recommended line of treatment for the patients infected by the coronavirus. But, with the help of several available vaccines, the number of infections is now decreasing in many countries. However, the longterm effectiveness of these vaccines is yet to be established.

The actual number of infected people and the resulting loss of lives cannot be accurately determined as a large number of infected people would have never approached a medical facility. According to [2], which concludes a study of 18 countries, the number of infections and loss of lives is much higher than reported. In some cases, the number is estimated to be are seventeen times higher than reported. Another report [3] asserts that by the end of 2020, half of 
India's population was likely to have been infected with the virus. Yet another report [4] concludes that by 3rd April, 2021, India would have passed one hundred million COVID-19 infections. If these reports to be are any guide, the worldwide infections may have already crossed the billion mark. That being the case, COVID-19 should be the most infectious pandemic of all time. Historically speaking, the pandemic of 1918-19, popularly known as Spanish flu [5] had caused an estimated fifty million deaths. However the number of people infected is not known. Details of several other pandemics, including COVID-19, can be found in [6].

COVID-19 has so far caused irreparable damage to many businesses and economies. There is hardly any sector which has escaped the devastation caused by the pandemic. It is very difficult to know the exact damage to different sectors and organisations. According to Statista [7], Global gross domestic product (GDP) currently stands at 176 trillion. According to [8], the novel corona virus has already accounted to a loss of sixteen trillion dollars, amounting to a loss of $9 \%$ of the global GDP. More details can be found in [6].

\subsection{Cost of COVID-19 on education}

COVID-19 had caught educational institutions, education managers, instructors and students off guard, most of whom were quite late to realize the gravity of the situation and hence delayed their response, causing much more damage than it should have. A section of them didn't know what to do whereas some others did not have ad-equate means to act decisively. As a result, millions of students missed out on all forms of formal education. However, some educational institutions were already using LMS, enabling them to switch to virtual classes.

Occurrence of future disasters and crises cannot be ruled out. Therefore, we should prepare and equip ourselves to prevail in the event of such crises. COVID-19 is an awakening for the world to redesign and readjust to the present and future realities of nature. In particular-lar, the education entities around the world and their governments should devise educational systems which sustain the shocks of future crises. It is a debatable question, whether nations should strive for a country-wide educational model of teaching or if individual institutions should be left to manage themselves. There are various arguments for both sides. For nations with low per capita income societies, a national model may be preferable.

\subsection{Contribution of this research}

COVID-19 has already caused extensive damage to the education sector throughout the world. According to a 2020
UNESCO report, nationwide closures have impacted over $91 \%$ of the world's student population. Saudi Arabia is not an exception. Many countries and institutions are formulating education models which can be effective under normal circumstances as well as in current and future crises.

The aim of this study is to propose a cost-effective and hybrid teaching model (CeHTM) for the King Abdulaziz University (KAU). As part of our research in this article, we shall review the current teaching practices at the KAU, which currently has 82 thousand students and is the leading university in the region. The CeHTM is based on an extensive study and an informal analysis of online and anonymous feedback surveys of about five thousand students and more than four hundred instructors of the KAU. Our focus in designing the CeHTM has been two fold, namely; (a) practicality and appropriateness of the teaching models for KAU, and (b) cost effectiveness without compromising quality and education. The proposed model is in conformity with the United Nations Report [9], and OECD Report [10]. Teaching model of the Saudi Arabian universities is remarkably similar. Hence, we expect that the CeHTM can be adapted by most of the Saudi Arabia, regional and global educational institutions.

\section{Literature review}

COVID-19 had forced many countries to clamp in to lockdown by suspending or severely curtailing social, educational and business activities. Many educational institutions had no choice but to halt face-to-face teaching and examinations. As outlined before, our aim in this paper is to propose a model for higher education which could withstand calamities and crises like the ongoing pandemic. Let's briefly review the effect of COVID-19 on education in different parts of the world, especially those with low GDP.

\subsection{Case of countries with low GDP}

Many countries of the world, especially those with low GDP, have struggled to deliver educational instructions to their students, including at the higher education level. A study by UNESCO in 2013 [11] found that only $1 \%$ of research was contributed by countries in the Sahara region of Africa. Another UNESCO report [12] found that the R\&D budget of Switzerland was 3.2\% of the GDP, compared to $0.3 \%$ for Sudan. The author in [13] wrote "African countries had no choice but to close their higher education institutions as part of their lockdown measures to contain the spread of the virus". These statistics point out the difficulties faced by some African countries in organizing 
their educational program by other means like online or distance learning. Only a few open universities in Africa had the capacity to switch to an online mode of education.

According to [14], only $23.8 \%$ of Indian households have internet access, while this figure is even lower (14.9\%) in rural areas. Moreover, only $16 \%$ of women had access to mobile internet, compared to $36 \%$ of men. Furthermore, most instructors are ill-equipped for online teaching. In China, schools and universities are deploying a mix of innovative and renewed approaches to ensure the right to education for all. Most developed countries were already using online education for certain courses, and so they were quick to switch over to virtual classes during the most difficult stages of the pandemic. However, organising laboratory classes and similar practical lesson was hard for all countries.

A study of education in India during the pandemic [15] has identified a lack of basic facilities, external distractions, family interruption during teaching and online examinations, a lack of training and technical support, barriers of budget for purchasing advanced technologies, and a lack of clarity and direction. While researching the case of India, another study [16] found network issues, a lack of training, and a lack of awareness of the major obstacles to provide education during the pandemic. According to [17], the Chinese government took concrete steps to ensure the continuation of education in virtual mediums. The authors in [18], while studying a dentistry study program at the Faculty of Dentistry Universitas Indonesia, have concluded that only $44 \%$ of students who took the survey preferred distance learning while at the same time $87 \%$ of them agreed that it required more time to study and review study materials.

\subsection{Case of the Middle East and North Africa}

The authors in [19] commented "For the first time in decades, countries in the Middle East and North Africa (MENA) are facing a common problem with no political or religious agenda that can nonetheless have devastating effects on millions of citizens". While studying the case of Middle East College Oman, according to [20], an abrupt migration to online learning took place due to the COVID19 pandemic, which created extreme disruptions for the students, educators, and managing staff. According to [21], higher education leaders in the Middle East and neighboring regions are generally upbeat about the results of the experiment in online learning that the COVID-19 pandemic forced upon them, but many say the experience has also exposed a number of problems that need to be addressed for e-learning to be used effectively. In [22], a survey based study of higher education in Morocco concluded that instructors and students prefer online learning for no more than half of the content and would like to have the other half of the syllabus to be completed face-to-face.

\subsection{Case of Saudi Arabia}

King Abdulaziz University of Saudi Arabia, located in the port city Jeddah, was one of the first Saudi Arabian higher educational institutes to swiftly and successfully implement online learning modes during the COVID-19 lockdown. Thousands of classes were conducted every week for the students of thirty seven faculties and centres were successfully moved to online mode in a seamless manner by the Deanship of e-Learning and Distance Education. Authors in [23] have carried out an extensive study, and proposed a KAU Pandemic Framework, which integrates five pillars of strategic adoption of social media: social media governance; social media resilience; social media utilization; decision-making capability; and institutional strategy. While studying the case of the undergraduate medical students of Qasim University, [24] found an overwhelming acceptance for online classes during the pandemic, and a recommendation that learning outcomes should be rigorously and regularly evaluated to monitor their effectiveness for future use of this mode in medical education. According to [25], pharmacy laboratory sessions at the King Saud University were replaced with video demonstrations of experiments, which were helpful but deficient in developing the hands-on skills a practicum would provide. Based on the results of a feedback questionnaire, the author in [26] has recommended stronger collaboration among Pharmacy colleges, and the formation of Saudi Association of Colleges of Pharmacy, especially during crises.

\subsection{Case of other countries}

In [27], challenges and opportunities for Russian higher education are discussed from teachers' perspective. The study found academic and students' readiness for online learning when the coronavirus problems were encountered. Authors in a Polish study [28], with the help of a feedback survey, conclude that the students welcomed changing to an online mode of teaching. This research is helpful in understanding the importance of distance learning. The response to higher education, based on an extensive feedback survey, in Spain, Italy and Ecuador was conducted in [29]. The study concludes that the pandemic created issues in meeting the demand for studying online and tools needed for use in a changed environment. In particular, it strained training resources, podcasts and, alternatives for traditional assignments and examinations. In [30], general observations are made about the higher education issues during COVID-19, which may be applicable to many 
countries whose cases are not discussed here. Furthermore, in [31], on the basis of a virtual mapping session of 79 faculties from different countries have concluded that students with financial and physical hardships would quite likely have fewer opportunities to have access to technology that would enable them to access education. Moreover, face-to-face learning provides a better chance for professionalism through enhanced team-work, and cognitive, communication and clinical skills are best achieved in a face-to-face environment.

\section{Methodology and results}

This article is a result of two questionnaires related to academic discourse at King Abdulaziz University (KAU), Jeddah, Saudi Arabia, one being for students, and the other for instructors at KAU. Both of these questionnaires were designed with a view of gaining knowledge about the L\&T experience of students and instructors during the COVID19 pandemic, and to gauge their views about proposed future models of teaching at KAU. These questionnaires were cleared by the relevant university body for seeking relevant demographic information, opinions, and expertise in dealing with online classes. Validity of the questionnaires was established by two independent experts. These questionnaires were administered through Blackboard. Before analyzing the responses, invalid responses were eliminated from the responses.

\subsection{Demographic information of student respondents}

The number of valid student responses to the questionnaire was $3939,60 \%$ of which were females. This represents a huge success for this kind of study, especially when it comes to reviewing teaching policies. Out of the total number of students, a breakup of different kinds of students is provided in Table 1 . These students represented thirty faculties. The maximum number (707) of them represented

Table 1 Student respondents

\begin{tabular}{lllll}
\hline & Frequency & Percent & Valid \% & Cumulative \% \\
\hline Regular student & 2954 & 75.0 & 75.0 & 75.0 \\
Distance education & 307 & 7.8 & 7.8 & 82.8 \\
Affiliate program & 236 & 6.0 & 6.0 & 88.8 \\
Diploma & 107 & 2.7 & 2.7 & 91.5 \\
Post graduate & 321 & 8.1 & 8.1 & 99.6 \\
Others & 14 & 4 & .4 & 100.0 \\
Total & 3939 & 100.0 & 100.0 & \\
\hline
\end{tabular}

the Faculty of Economics and Administration. There were 436 responses from the Faculty of Science, 299 from Engineering, 284 from Computing and Information Technology, 58 from Dentistry, and 52 from Applied Medical Sciences.

The computing skills of respondents are shown in Table 2. It is worth noting that $11.4 \%$ of respondents had a low level of computing skills. Table 3 shows the Blackboard usage experience. It should also be noted that $9.4 \%$ respondents had never used any learning management system (LMS).

\subsection{Demographic information of instructors}

A total of 414 instructors responded to the questionnaire. Different age groups are shown in Table 4. Interestingly enough, there were an equal number (207) of male and females instructors. This is remarkable as the number of female instructors in the university is far less than that of male instructors. From Table 5, we infer that close to 70\% respondents possessed $\mathrm{PhD}$ qualifications. Table 6 shows different ranks of the instructors. It is noteworthy that about $60 \%$ of the instructors are assistant professors or lecturers. Respondents from the instructors' category also represent thirty faculties of the KAU. Most of the instructors were found to be adequately experienced. Table 7 shows the breakup of theoretic and lab intensive courses. It is worth noting that more than $48 \%$ of courses deal with laboratory activity. Most of them had adequate proficiency in using Blackboard (Table 8), $11.6 \%$ instructors didn't use Blackboard during the March-July (Table 9), 26\% respondents did not receive any training of online teaching before the COVID-19 pandemic (Table 10).

\section{Responses to questionnaires}

Some responses from instructors and staff will be critically analyzed separately below.

Table 2 Computing skills of respondents

\begin{tabular}{llccc}
\hline & Frequency & Percent & Valid \% & Cumulative \% \\
\hline Intermediate & 1970 & 50.0 & 50.0 & 50.0 \\
Advanced & 1521 & 38.6 & 38.6 & 88.6 \\
Beginner & 448 & 11.4 & 11.4 & 100.0 \\
Total & 3939 & 100.0 & 100.0 & \\
\hline
\end{tabular}


Table 3 Blackboard experience

\begin{tabular}{llccc}
\hline & Frequency & Percent & Valid \% & Cumulative \% \\
\hline Less than a year & 1282 & 32.5 & 32.5 & 32.5 \\
More than 2 years & 1249 & 31.7 & 31.7 & 64.3 \\
Between 1-2 years & 1047 & 26.6 & 26.6 & 90.8 \\
Never used & 361 & 9.2 & 9.2 & 100.0 \\
Total & 3939 & 100.0 & 100.0 & \\
\hline
\end{tabular}

Table 4 Age of participants

\begin{tabular}{llccc}
\hline Frequency & Age & Percent & Valid \% & Cumulative \% \\
\hline $35-50$ & 236 & 57.0 & 57.0 & 57.0 \\
More than 50 & 115 & 27.8 & 27.8 & 84.8 \\
Below 35 & 63 & 15.2 & 15.2 & 100.0 \\
Total & 414 & 100.0 & 100.0 & \\
\hline
\end{tabular}

Table 5 Education level of participant

\begin{tabular}{llccc}
\hline & Frequency & Percent & Valid $\%$ & Cumulative \% \\
\hline Ph.D. & 286 & 69.1 & 69.1 & 69.1 \\
Masters & 128 & 30.9 & 30.9 & 100.0 \\
Total & 414 & 100.0 & 100.0 & \\
\hline
\end{tabular}

Table 9 Blackboard usage during March-July, 2020

\begin{tabular}{llrcc}
\hline & Frequency & Percent & Valid \% & Cumulative \% \\
\hline Yes & 366 & 88.4 & 88.4 & 88.4 \\
No & 48 & 11.6 & 11.6 & 100.0 \\
Total & 414 & 100.0 & 100.0 & \\
\hline
\end{tabular}

Table 10 LMS training before COVID-19

Table 8 Blackboard experience

\begin{tabular}{llrrc}
\hline & Frequency & Percent & Valid \% & Cumulative \% \\
\hline 0-1 year & 153 & 37.0 & 37.0 & 37.0 \\
1-2 years & 96 & 23.2 & 23.2 & 60.1 \\
More than 2 years & 165 & 39.9 & 39.9 & 100.0 \\
Total & 414 & 100.0 & 100.0 & \\
\hline
\end{tabular}

\begin{tabular}{llccc}
\hline & Frequency & Percent & Valid $\%$ & Cumulative \% \\
\hline Yes & 307 & 74.2 & 74.2 & 74.2 \\
No & 107 & 25.8 & 25.8 & 100.0 \\
Total & 414 & 100.0 & 100.0 & \\
\hline
\end{tabular}

Table 6 Rank of the participants

\begin{tabular}{llccc}
\hline & Frequency & Percent & Valid $\%$ & Cumulative \% \\
\hline Academic admin & 23 & 5.6 & 5.6 & 5.6 \\
Lecturer & 107 & 25.8 & 25.8 & 31.4 \\
Assistant professor & 142 & 34.3 & 34.3 & 65.7 \\
Associate professor & 72 & 17.4 & 17.4 & 83.1 \\
Professor & 58 & 14.0 & 14.0 & 97.1 \\
adjunct/industry & 12 & 2.9 & 2.9 & 100.0 \\
Total & 414 & 100.0 & 100.0 & \\
\hline
\end{tabular}

Table 7 Type of content taught

\begin{tabular}{llrrr}
\hline & Frequency & Percent & Valid \% & Cumulative \% \\
\hline Knowledge and basic competences (theoretical) & 215 & 51.9 & 51.9 & 51.9 \\
Knowledge and advanced competences (lab intensive) & 199 & 48.1 & 48.1 & 100.0 \\
Total & 414 & 100.0 & 100.0 & \\
\hline
\end{tabular}

\subsection{Instructor responses}

Item $\mathrm{Tl}$ Online education encourages interactivity more than face-to-face modes of delivery.

Response Only 101 out of 414 respondents agreed with the Item, as shown in Table 11. There was more disagreement amongst those with less than one year Blackboard experience or those with more than two years' experience.

Item T2 I prefer Blended learning in which online lectures, exams and face to face are mixed. 
Table 11 Effectiveness of online mode for continuity of education

\begin{tabular}{|c|c|c|c|c|c|c|c|}
\hline & & Completely Disagree & Disagree & Neutral & Agree & Completely Agree & Total \\
\hline \multirow[t]{3}{*}{ Teaching Blackboard Experience } & $0-1$ year & 1 & 7 & 16 & 65 & 64 & 153 \\
\hline & $1-2$ years & 1 & 4 & 6 & 38 & 47 & 96 \\
\hline & More than 2 years & 5 & 7 & 7 & 61 & 85 & 165 \\
\hline \multicolumn{2}{|l|}{ Total } & 7 & 18 & 29 & 164 & 196 & 414 \\
\hline
\end{tabular}

Fig. 1 Blended teaching

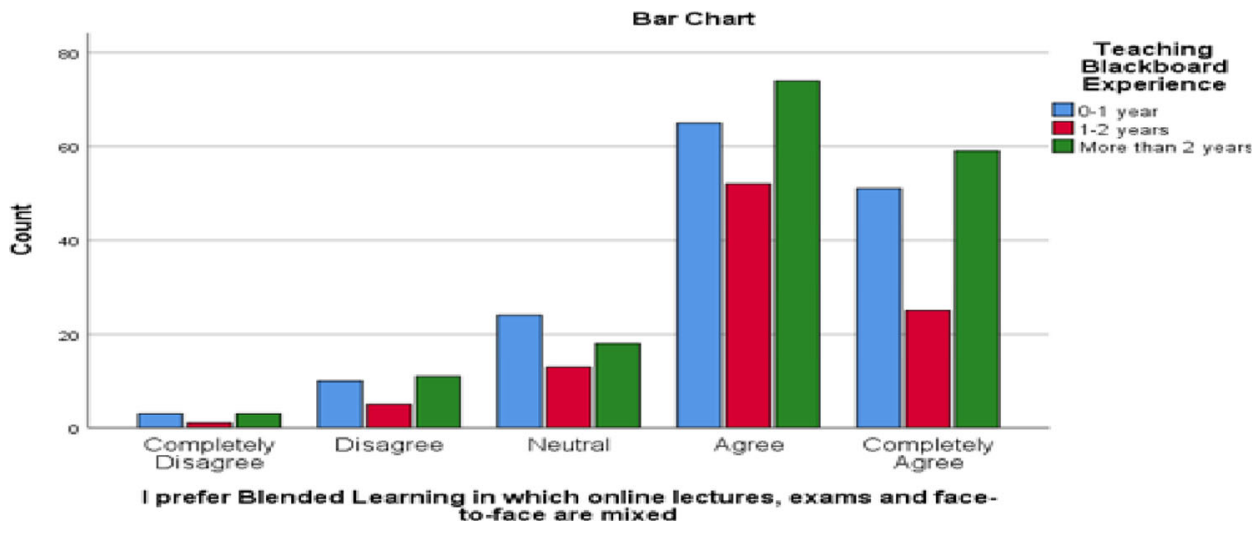

Response From Fig. 1, we can see that only 32 out of 414 respondents did not agree. Disagreement was more common amongst less experienced instructors.

Item T3 Online education encourages greater flexibility than face-to-face modes of delivery.

Response Only 101 out of 414 respondents agreed with the Item, as shown in Table 12. Hence, online education is not seen as a replacement to face-to-face modes of delivery.

Item T4 Online proctoring tools should be adopted.

Response More than $80 \%$ respondents use Blackboard Learn to monitor the students' performance, as can be seen from Fig. 2. All but 21 respondents agree to the use of online exam proctoring tools.

Item T5 Theoretical courses should be taught online.

Response A total of 125 disagreed, 86 were neutral, and 215 agreed, as shown in Fig. 3. Although the majority of instructors agreed, we cannot decisively claim this to be a norm for future.
Item T6 Laboratory intensive courses should be partially delivered online.

Response A total of 127 disagreed, 72 were neutral, and 205 agreed, as shown in Fig. 4. Again, the result show split opinions.

\subsection{Student responses}

As the number of student respondents was 3939, we find hundreds of agreements to every item. At the outset, it is worth to note that $11.4 \%$ students identified themselves as having a low level of working knowledge of information and computer technology (ICT), and 9.2\% students had never used Blackboard before. We have chosen to analyse the responses of those items, which are synonymous to those of instructors which we have analysed in the forgoing subsection. The responses to some of the critical propulsions are examined below.

Item S1 Online education ensured continuity of education during the COVID-19 outbreak.

Table 12 Interactivity of online education

\begin{tabular}{|c|c|c|c|c|c|c|c|}
\hline & & Completely disagree & Disagree & Neutral & Agree & Completely agree & Total \\
\hline \multirow[t]{3}{*}{ Teaching Blackboard Experience } & $0-1$ year & 30 & 65 & 28 & 22 & 8 & 153 \\
\hline & $1-2$ years & 14 & 33 & 25 & 18 & 6 & 96 \\
\hline & More than 2 years & 29 & 56 & 33 & 33 & 14 & 165 \\
\hline Total & & 73 & 154 & 86 & 73 & 28 & 414 \\
\hline
\end{tabular}


Fig. 2 Online proctoring tools

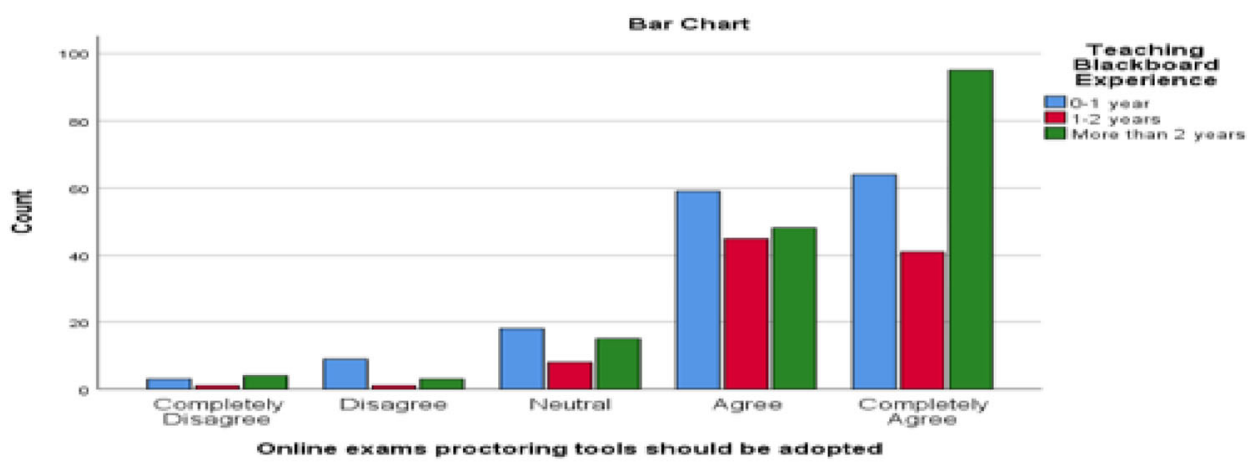

Fig. 3 Theoretical courses

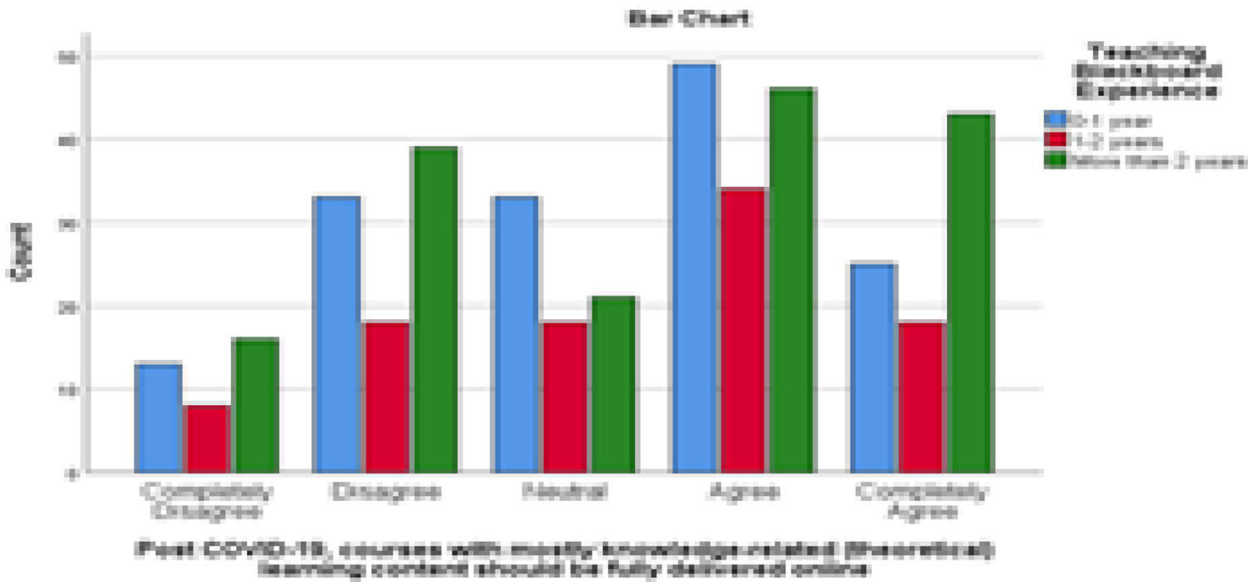

Fig. 4 Teaching Theoretical

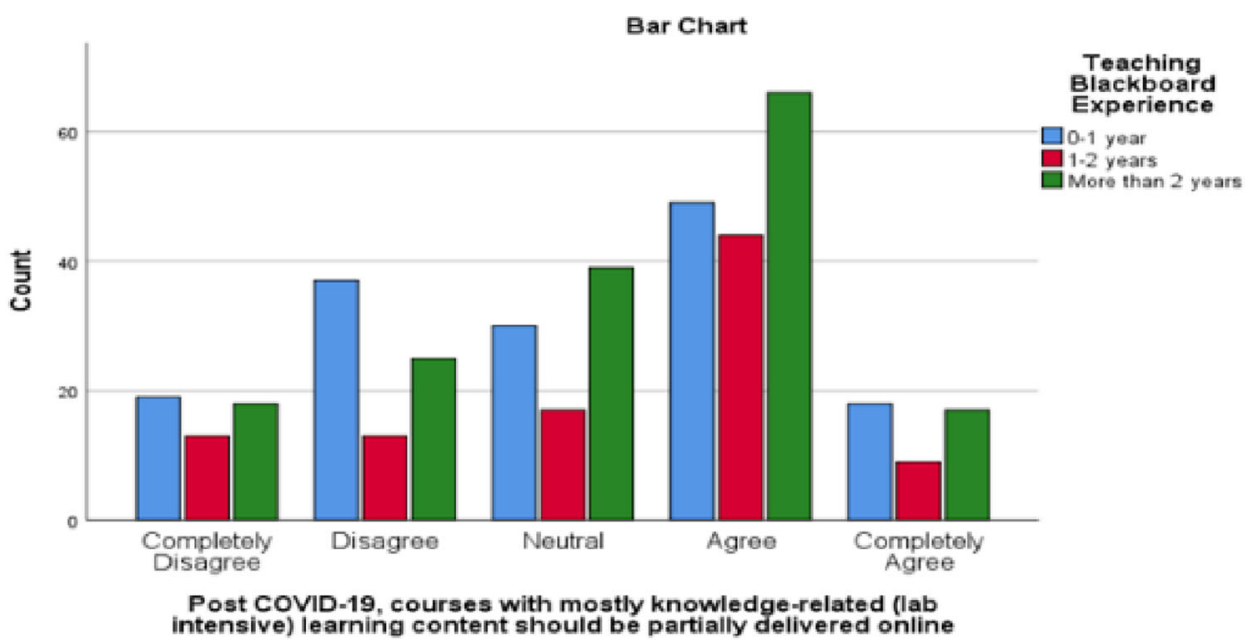
content in lockdown

Response A total of 1879 students agreed, out which 1017 were females. Nearly 600 disagreed, 432 of them were females. Out of 437 unsure, 300 were females (Fig. 5).

Item $S 2$ Online education encourages interactivity more than face-to-face modes of delivery.

Response As we can see in the Fig. 6, this item is hotly contested, and so the conclusions have to be drawn accordingly.
Response Responses to this item were mixed, as seen in Fig. 7.

Item S4 Theoretical courses should be taught online.

Response An overwhelming majority agrees with the proposition, as is evident in Fig. 8

Item S5 Laboratory courses should be taught online.

Response An overwhelming majority disagrees with the proposition, as can be seen in Fig. 9.

Responding to an item, "KAU should have a central and uniform approach for conducting virtual classes", there 
Fig. 5 Role of online education

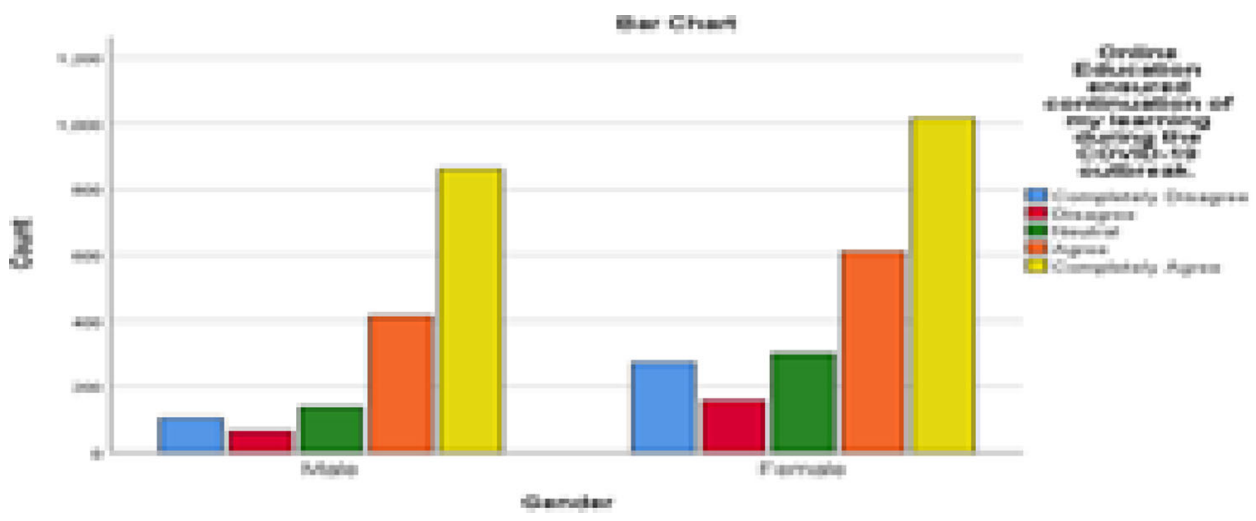

Fig. 6 Interactivity of online education

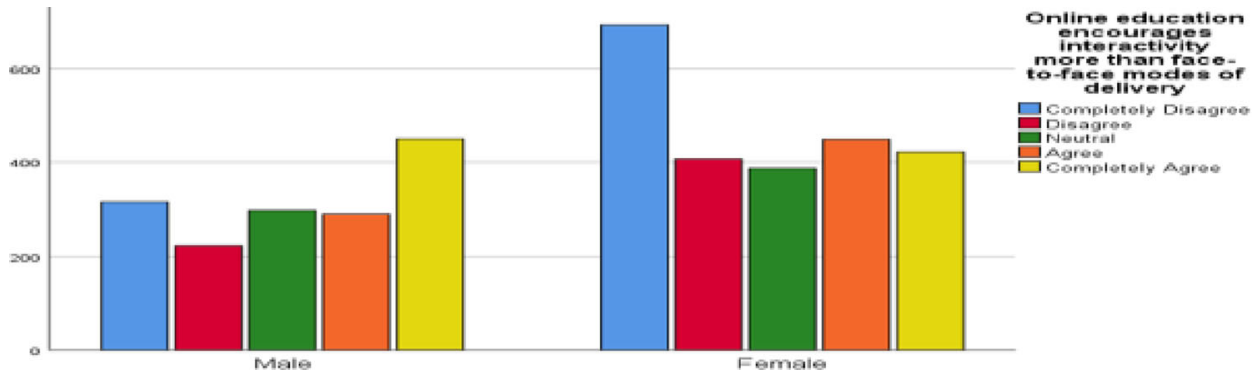

Fig. 7 Preference of online education

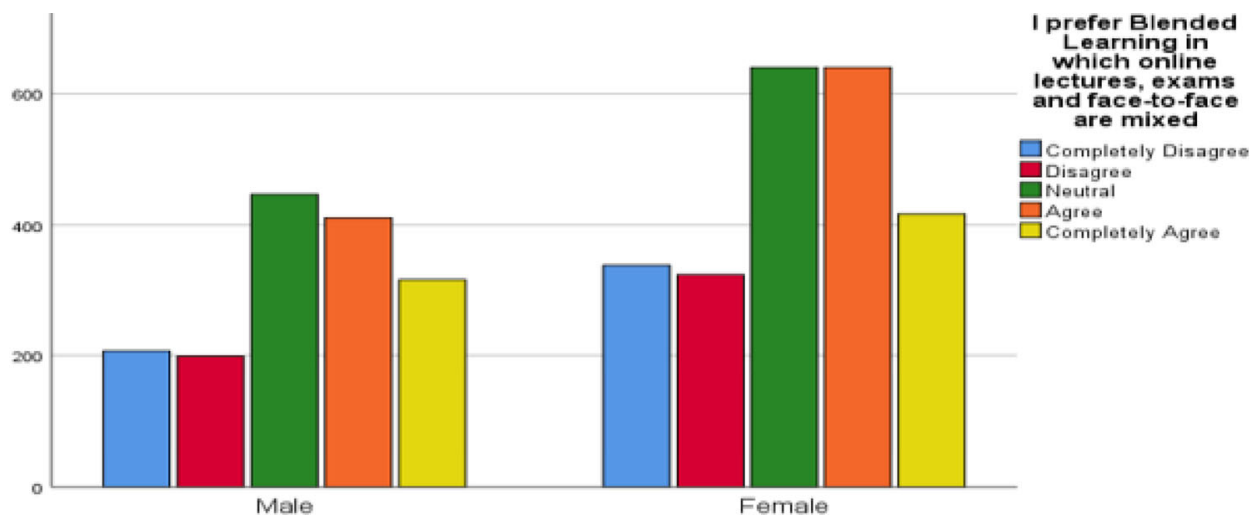

Fig. 8 Online education of theoretical content

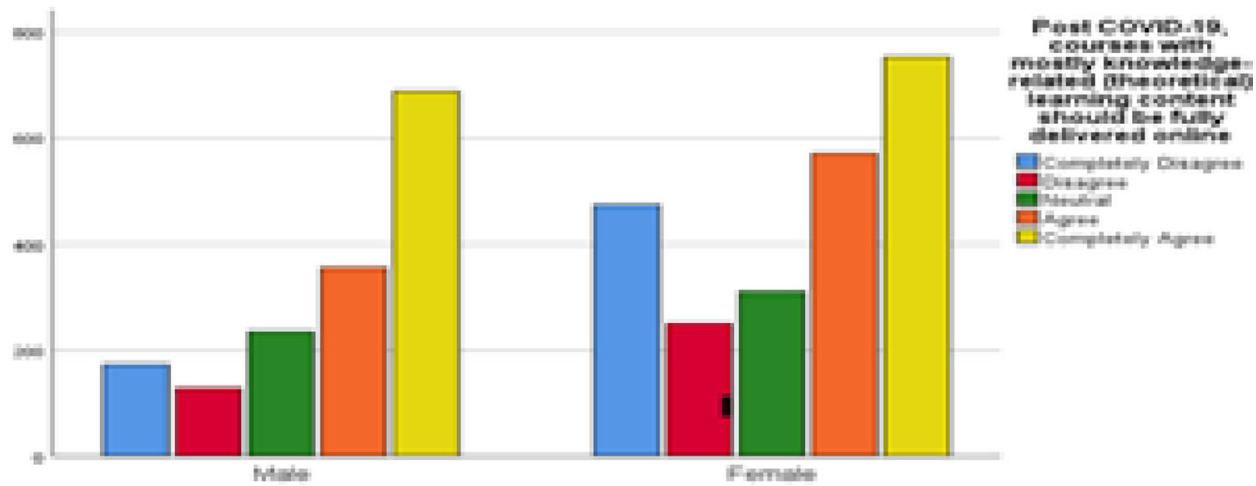

was an overwhelming agreement among participants. Similar was the response for "KAU should have a central and uniform approach for conducting virtual classes". There is no clear direction to the item "General, and
Foundation year courses should be fully delivered online Crosstabulation". 
Fig. 9 Online education of laboratory courses

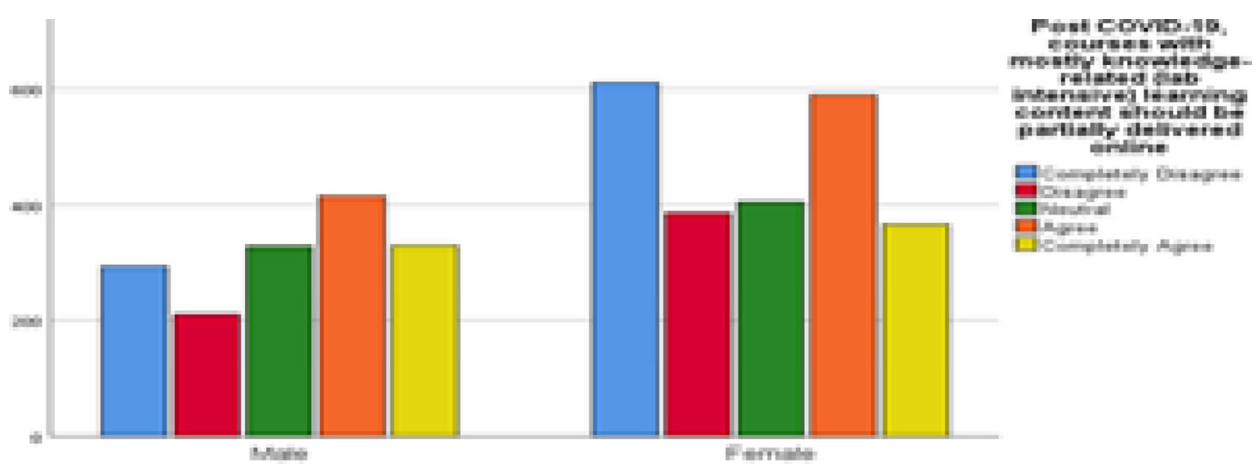

\section{Analysis of responses}

As was expected, the role of a LMS in the L\&T at the KAU during the COVID-19 has been lauded by the overwhelming majority of students, as well as teachers. Indeed, DeDE has outperformed many national, regional and global e-learning environments. In order to formulate a framework for a Cost-effective and Hybrid Teaching Model (CeHTM) for KAU, some of the responses will be critically analysed.

\subsection{Interactivity: online vs. face to face teaching}

The majority of instructors and students believe that face to face teaching is more interactive than online. $55 \%$ of instructors and $42 \%$ students think face to face teaching is more interactive, compared to only $24 \%$ of instructors and $38 \%$ of students who voted in favour of online teaching. About $21 \%$ of instructors and $22 \%$ of students expressed neutrality on the issue. From these statistics, we conclude:

a. The majority of teachers and students find face-to-face classes more interactive.

b. A larger percentage of instructors think that face-toface classes are more interactive compared to students.

\subsection{Preference for blended learning}

The overwhelming majority (79\%) of instructors prefer a blended mode of teaching as opposed to only $8 \%$ who think otherwise. Amongst the students, only $43 \%$ think that a blended mode of learning is preferable over the conventional methods but $27 \%$ think the opposite. These statistics are very interesting and somewhat unexpected because there is a significant number of students who prefer face to face teaching over blended modes of delivery. What's even more interesting is the fact that amongst students, the number of female students outnumber their male counterparts when it comes preferring face-to-face teaching over a blended mode. Therefore, we infer that
- Most instructors prefer a blended mode of teaching

- Although more students prefer a blended mode, there is a large population of students, especially females, who do not prefer a blended mode of teaching as opposed to the face-to-face mode.

\subsection{Preference for teaching theoretical courses online}

The majority of teachers (52\%) and students (60\%) agree that theoretical courses should be taught online. However, those who do not agree with this item are significant in number, namely $31 \%$ of teachers and $26 \%$ of students. Amongst the disagreeing students, the majority are female students. The following conclusions can be drawn:

- The majority of instructors and students are in favour of teaching purely theoretical courses online.

- There is a large portion of students $(26 \%)$ and teachers $(31 \%)$ who do not want theoretical courses to be taught online.

- Among the students who do not prefer online teaching, about $70 \%$ are female.

\subsection{Preference for teaching lab-intensive courses online}

On the question of teaching laboratory related courses online, only $43 \%$ are in favour of it, while $38 \%$ are against and $21 \%$ are neutral. Similarly, $49 \%$ instructors were found to be in favour, $30 \%$ in disagreement and $19 \%$ neutral. The following conclusions can be drawn from these statistics:

- Nearly half the teachers have no issues in teaching lab related courses online.

- Student opinion is very much divided, with no clear uniform response.

- The number of females who disagree is about twice that of male students. 


\subsection{Online examinations}

The majority of students agreed that KAU should have a central and uniform approach for conducting examinations. The majority of teachers would like to use Black-board Learn to monitor students' performance. The author in [25] has presented evidence of rampant cheating in online examinations during COVID-19 lockdowns, and suggested implementing a uniform online exam policy by capturing each student's computer screen and room with a camera.

\subsection{Some other inferences}

The majority of students did not agree that first year and foundation courses should be taught face to face but the opposition to this was very strong as well. The majority of students agreed that KAU should have a central and uniform approach for conducting virtual classes, and examinations and that KAU should a central database for online teaching material.

\section{Cost-effective and hybrid teaching model (CeHTM)}

Based on the analysis of the responses of student and instructors' surveys, we pro-pose a CeHTM. Figure 10 shows the Frame-work for CeHTM, complimented by Table 13, which contains of list of activities aimed at providing a cost effective, qualitative and sustainable model of teaching in normal circumstances, which forms the basis of the CeHTM. These activities are drawn in view of the preceding analysis of the responses of students and instructors. A significant number of these activities are already being enforced at KAU through the Deanship of e-Learning and Distance Education. The important parts of the CeHTM are explained below.

\subsection{Constituents of CeHTM}

'Course' or 'Unit' have been made as the parent module of CeSTM. We have identified class, assessments, LMS (blackboard, in case of KAU), Recorded lectures, student feedback, and course file as the submodules of 'Unit', which are described below.

\subsubsection{Class}

A class may be onsite or online. It may be a theoretical, practical, or a lab class for all cohorts (Post Graduate (PG), Undergraduate (UG), Diploma (Dip), Certificate (Cer), Laboratory (Lab), Practical (Pra), etc. We have recommended that at least $50 \%$ of each PG class lectures should be delivered online. Similarly, we have recommended that at least $50 \%$ of lectures of all UG, Dip, and Cer, and Pra courses should be delivered face-to-face onsite. The size of an online class can be considerably larger and a larger class may be taught by one or more instructors. In case of emergencies and crises, like COVID-19, all classes can be taught online. We suggest that all lectures, both onsite and online, must be recorded and be provided on the unit website.

\subsubsection{Assessment}

A unit may have one or more assessments, comprising of assignments, tests, and the final examination. In view of [25] and other studies, plagiarism is a serious problem associated with online examinations. Indeed, there may be courses which may have continuous assessment based on case studies, and may not require formal examinations. In cases of a crisis, like the ongoing pandemic, virtual classes and online examinations for all courses would be a natural option. In case of an online examination, proctoring mechanisms, like video surveillance of the computer and the room should be enforced. Instructors should be provided with adequate training to design online tests based on randomly selected questions from pools. In normal circumstances, we recommend that all final examinations should be conducted on campus. Mid semester tests, if required, may be conducted online. Other assessments, including oral presentations, can be conducted online.

Assignment submissions must be accepted through specially created drop boxes on the unit website. For online tests and examinations, questions pools should be created to generate varying assessments for different students. We strongly recommend using proctoring tools for online examinations. The university must provide adequate training for this. We also suggest that students should be given an opportunity to review the marking of their examinations. It is a practice in many universities which facilitates students being able to view instructors' marking of their final examinations. We also suggest that the final grades should be approved by a colleague before submitting them for acceptance and publication.

\subsubsection{Learning management system}

A LMS is a content management system, which is very suitable to serve as a content repository and manager of teaching activities. The KAU uses blackboard, where all university courses are hosted, to provide a unit outline, course related material, and information. We recommend that all instructors and students should be provided adequate training to enable effective use of the LMS. All new instructors must be provided mandatory training in the first 


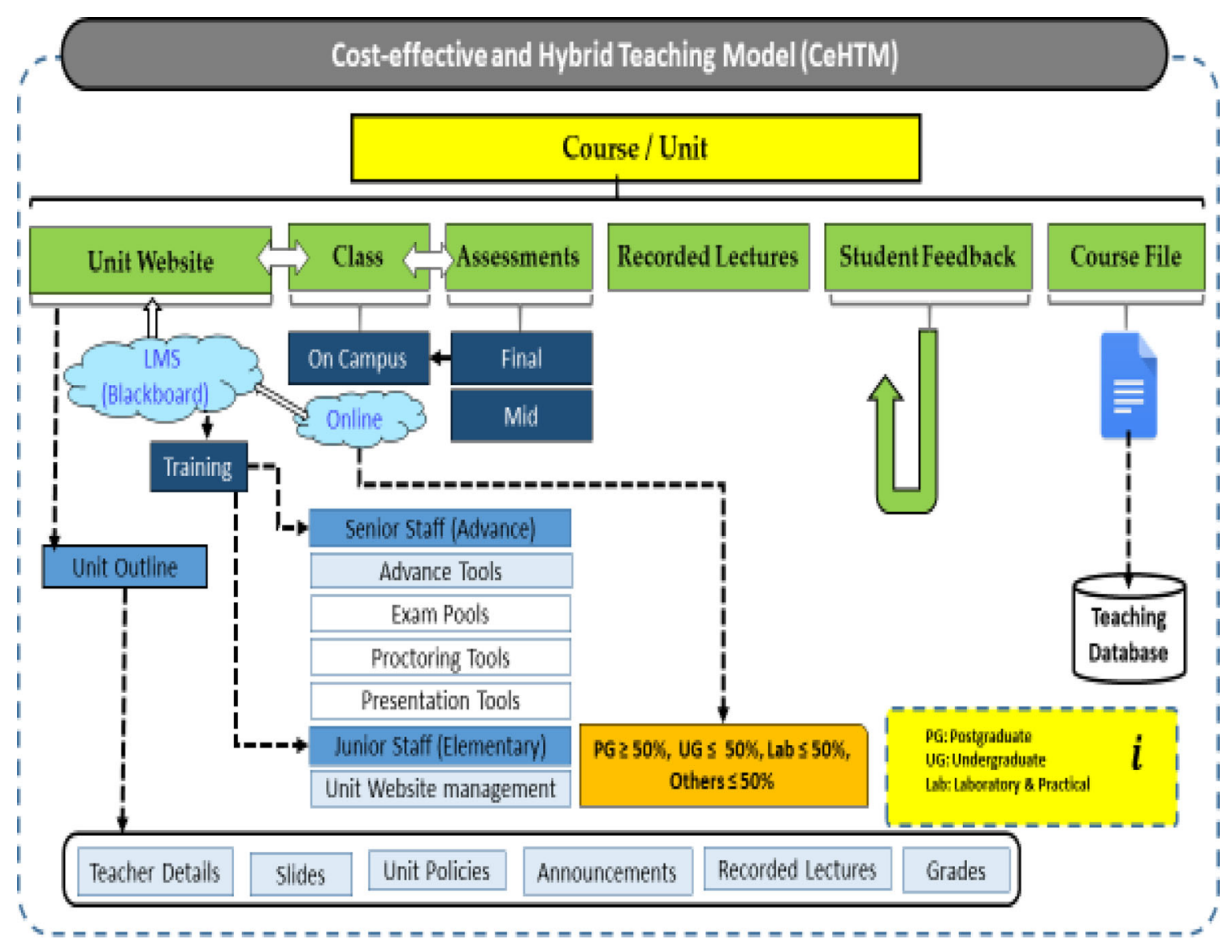

Fig. 10 Framework of CeHTM

year of their teaching. Senior staff, with two or more years of experience should be provided with advanced con-tent management training, to enable them to design pool based tests and exams, online presentations, online marking, and proctoring tools to supervise online tests and exams.

\subsubsection{Unit website}

A unit website is the most important online document for teaching and learning. To make it truly meaningful and interactive, a unit outline must be designed with great attention to detail. We suggest that the course outline should be approved by another faculty peer, normally an experienced colleague. Moreover, a unit online should not be changed except with unanimous approval by the students. A unit outline must provide adequate details of all instructors for the unit, along with their student-meeting times, and contact details. Course description and course policies should be clearly outlined. Ongoing announcements should be placed on the website, which by default are automatically emailed to all students. Student presentations should also take place on the website powered by the content management system. All assignments should be received through specially created drop boxes on the website. Plagiarism checking and online marking can be facilitated by the LMS. Video recordings of all lectures (online as well as offline) must be provided through LMS. Grades of all student assessments should be promptly displayed on the unit website. Each unit website should have a folder for submitting course files of the main content and information, including all assessment details and grades of the unit at the conclusion of teaching. This folder should have a link to the faculty-based database for course files. We suggest a standard format for a course file, to be designed and implemented by each faculty.

\subsubsection{Student feedback}

Feedback is way to know the effectiveness of a current course. It should be made mandatory for all classes, and should be administered online after completion of the teaching but before the final examination. Indeed, if a teacher wants to improve her/his course delivery, one of the best ways is to administer and analyse the results of students' feedback. Student feedback is instrumental to improve the content, course delivery, and other course related items. Anonymous student feedback can be received through the LMS. We recommend the university 
Table 13 Details of CeHTM

\begin{tabular}{|c|c|c|c|}
\hline $\mathrm{SN}$ & Event & Affected population & Action \\
\hline 1 & $\begin{array}{l}\text { Online and blended classes } \\
\text { 1. Postgraduate courses online } \\
\text { 2. Undergraduate classes } \\
\text { 3. Lab classes without chemical/ } \\
\text { equipment }\end{array}$ & $\begin{array}{l}\text { All faculties } \\
50-100 \% \\
0-50 \% \\
50-100 \% \text { Comp, Eng. Science, } \\
\text { Med }\end{array}$ & $\begin{array}{l}\text { Notify before semester start } \\
\text { Increase class size, and assign two or more instructors to } \\
\text { each class }\end{array}$ \\
\hline 2 & $\begin{array}{l}\text { LMS (blackboard) training } \\
\text { 1. Elementary } \\
\text { 2. Advanced } \\
\text { 3. Innovative exam design } \\
\text { 4. Marking tools }\end{array}$ & $\begin{array}{l}\text { All instructors } \\
\text { New/casual instructors } \\
\text { Senior instructors } \\
\text { Senior instructors } \\
\text { Senior instructors }\end{array}$ & $\begin{array}{l}\text { Each semester } \\
\text { During orientation week } \\
\text { During orientation weeks } \\
\text { In the middle of the semester } \\
\text { In the middle of the semester }\end{array}$ \\
\hline 3 & $\begin{array}{l}\text { Examination } \\
\text { 1. On campus mid semester exams } \\
\text { 2. On campus final exams } \\
\text { 3. Online exams }\end{array}$ & $\begin{array}{l}\text { All faculties } \\
\text { All classes (except in case of } \\
\text { crisis) } \\
\text { All classes (except in case of } \\
\text { crisis) } \\
\text { If required (crisis) }\end{array}$ & $\begin{array}{l}\text { Notify at the start of semester } \\
- \\
- \\
\text { Proctoring mechanism }\end{array}$ \\
\hline 4 & Course outline & All units/courses & Host on LMS \\
\hline 5 & $\begin{array}{l}\text { 1. Unit policies } \\
\text { 2. Slides and lecture notes } \\
\text { 3. Announcements } \\
\text { 4. Lecture recordings (all lectures) } \\
\text { 5. Grades of all assessments } \\
\text { 6. Other course material }\end{array}$ & & \\
\hline 6 & Student feedback (online) & All classes & Administer on LMS \\
\hline 7 & $\begin{array}{l}\text { Review by students of their final exam } \\
\text { marking }\end{array}$ & After all final exams & As per university calendar \\
\hline
\end{tabular}

to make it mandatory to facilitate students to provide online feedback for each course of study at least once, usually at the end of the semester. University should make arrangement to compile and process student feedback to send them to the concerned instructors and faculties. Each department should discuss cumulative performance of the teaching and take steps to remove problems, if any arise. Instructors can learn from the feedback and make improvements in their delivery and discourse management. Faculties can use the student feedback to assess and reward the three best teachers within the faculty.

\subsubsection{Lecture recording}

To ensure quality and transparency in teaching, we suggest that the face-to-face on-campus and online lectures should be video recorded. These recordings should be made available to the students through the unit website. These recordings can also be part of the department, faculty or university databases. Once they are in the database, many new instructors may find them to be quite instructive.

\subsubsection{Review of exam marking by students}

It is also suggested that students be given a chance to review the marking of their ex-aminations each semester. It is a practice in many universities to facilitate students being able to view instructors' marking of their final examinations. This mechanism provides transparency in marking the examinations. Sometimes some calculation errors may also be rectified.

\subsubsection{Course file and teaching database}

Course files must be prepared for each unit at the completion of teaching in each semester. We recommend a uniform template for a course file. A template should be designed by each faculty after considering their requirements. Usually a course file includes a unit outline, specimen of lecture slides, test and examination papers, scanned copies of some scripts to demonstrate the variation in marking, and examination grades. Scanned copies of all course details should be submitted to a specially designed 
database, which can become part of the national database, faculty wise.

\subsubsection{Cost effectiveness of CeHTM}

The CeHTM is not only smart and innovative, but also a cost effective model. Let us briefly describe cost effectiveness of policies and measures inbuilt in the CeHTM. Online class size can be substantially bigger than the usual size of face-to-face classes. In order to ensure quality, in some cases, more than one instructor may be assigned to the same online class. Increasing class size will drastically reduce the overall number of instructors required by the university. Online classes will require much fewer support staff, classrooms and other infrastructure. Less infrastructure would amount to less maintenance and would eradicate the need for new classrooms and buildings. These measures will result in enormous savings to the university budget.

\section{Conclusions}

During a crisis, there cannot be an absolutely flawless teaching system. However, with the help of informed decisions, degradation and poor performance can be minimized. Often, educational institutes and students in low GDP countries struggle for basic infrastructure, in addition to the problems which others face. Our survey, amongst many other things, has found that students and instructors favour uniform national educational policies.

Our proposed system, if properly implemented, is expected to provide remarkable benefits to the educational institutions and hence the country. In the case of Saudi Arabia, we find remarkable similarities in all state-run educational institutions. This being the case, our proposed framework for the CeHTM can be adapted by all educational institutions in Saudi Arabia. It may also be quite useful for other countries, especially in the Middle East and Northern Africa.

\section{References}

1. World Health Organization (WHO) (2020) Rolling updates on coronavirus disease (COVID-19). [Online]. Accessed 31 March, 2021 from http://www.euro.who.int/en/health-topics/health-emer gencies/coronavirus-covid-19/news/news/2020/3/who-announ ces-covid-19-outbreak-a-pandemic

2. Phipps SJ, Grafton RQ, Kompas T (2020) Robust estimates of the true (population) infection rate for COVID-19: a backcasting approach. R Soc Open Sci. https://doi.org/10.1098/rsos.200909

3. The New Indian Express (2020) 50 per cent of Indian population could be COVID-19 infected by December: NIMHANS
Neurovirology head. Accessed 31 March, 2021 from https:// www.newindianexpress.com/states/karnataka/2020/may/28/50per-cent-of-indian-population-could-be-covid-19-infected-bydecember-nimhans-neurovirology-head-2148985.html

4. Taubenberger JK (2006) The origin and virulence of the 1918 "Spanish" influenza virus. Proc Am Philos Soc. 150(1):86-112 ((PMID: 17526158 PMCID: PMC2720273))

5. Yamin M (2020) Counting the cost of COVID-19. Int J Inf Tecnol 12:311-317. https://doi.org/10.1007/s41870-020-00466-0

6. Statista (2009) Global gross domestic product (GDP) at current prices from 2009 to 2021. Online. Accessed 31 March, 2021 from https://www.statista.com/statistics/268750/global-gross-domes tic-product-gdp/\#: :text=In\%202019\%2C\%20global\%20GDP $\%$ 20amounted $\% 20$ to $\% 20$ about $\% 20142 \% 20$ trillion $\% 20$ interna tional\%20dollars

7. Cutler DM, Summers LH (2020) The COVID-19 pandemic and the $\$ 16$ trillion virus. JAMA 324(15):1495-1496. https://doi.org/ 10.1001/jama.2020.19759

8. United Nations (2020) Education during COVID-19 and beyond. Online. Accessed 31 March, 2021 from https://www.un.org/ development/desa/dspd/wp-content/uploads/sites/22/2020/08/sg_ policy_brief_covid-19_and_education_august_2020.pdf

9. Schleicher A (2020) The impact of covid-19 on education (insights from education at a glance 2020). OECD report. Accessed 31 March, 2021 from https://www.oecd.org/education/theimpact-of-covid-19-on-education-insights-education-at-a-glance2020.pdf.

10. UNESCO SCIENCE REPORT. Published in 2015 by the United Nations Educational, Scientific and Cultural Organization. Accessed 31 March, 2021 from http://uis.unesco.org/sites/default/ files/documents/unesco-science-report-towards-2030-part1.pdf (ISBN 978-92-3-100129-1)

11. UNESCO Institute of Education. How much your country invest in R\&D. Online. Accessed 31 March, 2021 from http://uis. unesco.org/apps/visualisations/research-and-developmentspending/

12. Goolam MB (2020) AFRICA: COVID-19: what consequences for higher education? University World News. 09 April 2020. Online. Accessed 31 March, 2021 from https://www.uni versityworldnews.com/post.php?story $=20200407064850279$

13. Shahni S (2020) COVID-19 in India: education disrupted and lessons learned. Brookings. Accessed 31 March, 2021 from https://www.brookings.edu/blog/education-plus-development/ 2020/05/14/covid-19-in-india-education-disrupted-and-lessonslearned/

14. Joshi A, Vinay M, Bhaskar P (2020) Impact of coronavirus pandemic on the Indian education sector: perspectives of teachers on online teaching and assessments. Interact Technol Smart Educ. https://doi.org/10.1108/ITSE-06-2020-0087

15. Arora AK, Srinivasan R (2020) Impact of pandemic COVID-19 on the teaching-learning process: a study of higher education teachers. Prabandhan Indian J Manag. https://doi.org/10.17010/ pijom/2020/v13i4/151825

16. Zhu X, Liu J (2020) Education in and after covid-19: immediate responses and long-term visions. Postdigit Sci Educ 2:695-699. https://doi.org/10.1007/s42438-020-00126-3

17. Amir LR, Tanti I, Maharani DA et al (2020) Student perspective of classroom and distance learning during COVID-19 pandemic in the undergraduate dental study program Universitas Indonesia. BMC Med Educ 20:392. https://doi.org/10.1186/s12909-02002312-0

18. Mohammad Karamouzian M, Madani N (2020) COVID-19 response in the Middle East and North Africa: challenges and paths forward. Lancet Glob Health 8(7):E886-E887. https://doi. org/10.1016/S2214-109X(20)30233-3 
19. Mohmmed AO, Khidhir BA, Nazeer A et al (2020) Emergency remote teaching during Coronavirus pandemic: the current trend and future directive at Middle East College Oman. Innov Infrastruct Solut 5:72. https://doi.org/10.1007/s41062-020-00326-7

20. Senthil N (2020) Where does higher education go from here? Al Fanar Media. Accessed 31 March, 2021 from https://www.alfanarmedia.org/2020/05/future-higher-education-go-from-here/

21. El Firdoussi S, Mohamed LM, Kabaili H, Driss R, El Firdoussi L (2020) Assessing distance learning in higher education during the COVID-19 pandemic. Educ Res Int 2020:8890633. https://doi. org/10.1155/2020/8890633

22. AI-Youbi AO, Al-Hayani A, Bardesi HJ, Basheri M, Lytras MD, Aljohani NR (2020) The King Abdulaziz University (KAU) pandemic framework: a methodological approach to leverage social media for the sustainable management of higher education in crisis. Sustainability 12:4367

23. Khalil R, Mansour AE, Fadda WA et al (2020) The sudden transition to synchronized online learning during the COVID-19 pandemic in Saudi Arabia: a qualitative study exploring medical students' perspectives. BMC Med Educ 20:285. https://doi.org/ 10.1186/s12909-020-02208-Z

24. Almetwazi M, Alzoman N, Al-Massarani S, Alshamsan A (2020) COVID-19 impact on pharmacy education in Saudi Arabia: challenges and opportunities. Saudi Pharm J 28(11):1431-1434. https://doi.org/10.1016/j.jsps.2020.09.008 ((ISSN 1319-0164))

25. Alqurshi A (2020) Investigating the impact of COVID-19 lockdown on pharmaceutical education in Saudi Arabia - a call for a remote teaching contingency strategy. Saudi Pharm J 28(9):1075-1083. https://doi.org/10.1016/j.jsps.2020.07.008 ((ISSN 1319-0164))

26. Eren Bilen E, Matros A (2021) Online cheating amid COVID-19. J Econ Behav Organ 182:196-211. https://doi.org/10.1016/j.jebo. 2020.12.004 ((ISSN 0167-2681))

27. Almazova N, Krylova E, Rubtsova A, Odinokaya M (2020) Challenges and opportunities for Russian higher education amid COVID-19: teachers' perspective. Educ Sci 10:368. https://doi. org/10.3390/educsci10120368

28. Rizun M, Strzelecki A (2020) Students' acceptance of the COVID-19 impact on shifting higher education to distance learning in Poland. Int J Environ Res Public Health 17:6468. https://doi.org/10.3390/ijerph17186468

29. Tejedor S, Cervi L, Pérez-Escoda A, Tusa F, Parola A (2021) Higher education response in the time of coronavirus: perceptions of teachers and students, and open innovation. J Open Innov Technol Mark Complex 7:43. https://doi.org/10.3390/ joitmc7010043

30. Bajaba S, Mandurah K, Yamin M (2021) A framework for pandemic compliant higher education national system. Int J Inf Tecnol. https://doi.org/10.1007/s41870-021-00629-7

31. Ahmed SA, Hegazy NN, Abdel Malak HW et al (2020) Model for utilizing distance learning post COVID-19 using (PACT) TM a cross sectional qualitative study. BMC Med Educ 20:400. https:// doi.org/10.1186/s12909-020-02311-1 